\title{
Article \\ Hibiscus rosa-sinensis as Flavoring Agent for Alcoholic Beverages
}

 \\ Laura Pistelli $2,4, *$ (D) and Guido Flamini $1,2, * \mathbb{D}$ \\ 1 Dipartimento di Farmacia, Università di Pisa, Via Bonanno 6, 56126 Pisa, Italy; \\ ylenia.pieracci@phd.unipi.it (Y.P.); luisa.pistelli@unipi.it (L.P.); m.lari5@studenti.unipi.it (M.L.); \\ roberta.ascrizzi@gmail.com (R.A.) \\ 2 Centro Interdipartimentale di Ricerca Nutraceutica e Alimentazione per la Salute 'NUTRAFOOD', \\ Università di Pisa, Via del Borghetto 80, 56124 Pisa, Italy \\ 3 Circolo ARCI La Staffetta, Via Don Minzoni 29, Calci, 56011 Pisa, Italy; arcilastaffetta@gmail.com (M.I.); \\ andreamarianelli93@gmail.com (A.M.) \\ 4 Dipartimento di Scienze Agrarie, Alimentari e Agro-Alimentari, Università di Pisa, Via del Borghetto 80, \\ 56124 Pisa, Italy \\ * Correspondence: laura.pistelli@unipi.it (L.P.); guido.flamini@unipi.it (G.F.)
}

Citation: Pieracci, Y.; Pistelli, L.; Lari, M.; Iannone, M.; Marianelli, A.; Ascrizzi, R.; Pistelli, L.; Flamini, G. Hibiscus rosa-sinensis as Flavoring Agent for Alcoholic Beverages. Appl. Sci. 2021, 11, 9864. https://doi.org/ 10.3390/app11219864

Academic Editors: Ilda Caldeira and Mar Vilanova

Received: 29 September 2021

Accepted: 20 October 2021

Published: 22 October 2021

Publisher's Note: MDPI stays neutral with regard to jurisdictional claims in published maps and institutional affiliations.

Copyright: (c) 2021 by the authors. Licensee MDPI, Basel, Switzerland. This article is an open access article distributed under the terms and conditions of the Creative Commons Attribution (CC BY) license (https:/ / creativecommons.org/licenses/by/ $4.0 /)$.

\begin{abstract}
The present work is an evaluation of the chemical composition of the aroma and the sensorial characters of a beer flavored with Hibiscus rosa-sinensis flowers. Moreover, the total polyphenol, flavonoid and anthocyanin contents and the antioxidant activity of the plant materials and beers were assessed. A comparison with a liqueur flavored with the same hibiscus flowers was also performed. Non-terpene derivatives constituted the main class of components of the aroma of both samples, representing $96.4 \%$ of the whole volatilome in the control beer and $99.0 \%$ in the hibiscus one. Among this class, esters were the most abundant compounds, being significantly higher in the treated sample $(77.6 \%)$ than in the control $(68.4 \%)$, followed by the alcohols $(20.9 \%$ in control beer and $18.8 \%$ in hibiscus beer). From a sensorial point of view, the control beer was characterized by malty and hoppy notes, attributable to the noticeable content in myrcene and $\alpha$-humulene in its headspace, while in the hibiscus beer, floral and fruity notes, typical of esters and alcohols, prevailed. The polyphenol content was significantly higher in the treated beer $(143.96 \mathrm{mg} / \mathrm{g})$ than in the control, as well as the total flavonoids and the total anthocyanins, and, consequently, the antioxidant activity (DPPH-assay).
\end{abstract}

Keywords: Chinese hibiscus; beer; pale ale; liqueur; HS-SPME; GC-MS; QDA; panel test; polyphenol content; DPPH-assay

\section{Introduction}

Beer is one of the most popular alcoholic beverages consumed worldwide. It is defined as the product of the yeast fermentation of cereal soluble sugar, usually flavored with hops [1]. Nowadays, the craft beer industry constitutes a growing economic sector, as consumers perceive artisanal beers as a higher quality product, thanks to the several varieties of flavors they can present, different from those found in commercial beers $[2,3]$. Along with factors related to the purchasing process, consumer preferences are affected by the beer sensory characters [4], particularly aroma, flavor, mouthfeel and appearance, determined by both the brewing process and the ingredients $[5,6]$. The beer flavors and aromas, resulting from a complex balance of several volatile compounds rather than a single constituent $[7,8]$, are ascribed to the used raw materials and to the brewing process. Undoubtedly, hop (Humulus lupulus L.) is the main contributor to the aroma of the final product [9], being responsible for the peculiar and appreciated hoppy scents, which are directly related to the volatile composition of its essential oil (EO) [10]. However, the aroma characters of the other raw starting materials used in the brewing process influence 
the final product bouquet, as well, as evidenced by Ascrizzi et al. (2020), whose study reported the flavoring of a beer with hemp flowers [7]. Along with the volatile organic compounds (VOCs), polyphenols play a crucial role in consumer preferences. These secondary metabolites decisively influence the sensorial quality of the beer, contributing also to its astringency, body and color [2,6]. Astringency and body are two significant attributes of the mouthfeel, defined also by other parameters which together concur to modify the release of the volatile compounds, influencing the whole sensorial character of the final product [11,12]. Finally, the color is an important visual feature of the beer, as well as of the other foods and drinks, because it can influence the consumers' experience determining expectations on taste and flavor of the product [13]. The color depends on both the type of employed grains and the processes they under-went during the brewing: mashing and wort boiling are key phases in the color formation, since they determine several chemical modifications, including the caramelization of sugars, oxidation of polyphenols and the Maillard reaction [1,14], which is of the utmost importance in the flavor development [9]. Therefore, each sensory character of the beer is strictly connected to each other, and together they contribute to determining the organoleptic profile of the final product [15].

In recent decades, an increasing interest to propose new flavored beers has been noticed. Hibiscus rosa-sinensis L. is an appropriate candidate to achieve this goal, as its red flowers are widely used in traditional food as a flavoring agent [14], as well as in local medicine for their antipyretic, analgesic, anti-asthmatic and anti-inflammatory activities [15-17] due to its secondary metabolites content [16]. H. rosa-sinensis, also known as "Chinese hibiscus" or "tropical hibiscus" [15], is a perennial shrub belonging to the Malvaceae family, typical of tropical areas [15,16]. It is a plant of considerable commercial importance due to its presence in several herbal remedies [16]. Although H. rosa-sinensis is harvested for different plant parts, flowers are the most employed ones. Among the different bioactive compounds contained in the flowers, polyphenol compounds are of the utmost importance for their antioxidant properties [18]. Polyphenols, in fact, are key components in the food industry and are widely exploited to maintain oxidative stability $[19,20]$ as they work as scavengers of free radicals and as natural metal chelators [19], contributing to several sensorial characters and prolonging products' shelf-life [21,22].

The present study aimed to evaluate the volatile chemical composition and the sensorial properties of a beer flavored with $H$. rosa-sinensis flowers, in addition to the H. lupulus "Cascade" cones. Moreover, the total polyphenol, flavonoid and anthocyanin contents of the plant materials and beers were assessed, together with their antioxidant activity. A comparison with a liqueur flavored with the same hibiscus flowers was also performed, to assess the different aroma contribution of the same plant material to a different matrix: the liqueur, in contrast with beer, is not characterized by a defined aroma, which is, thus, completely determined by the used flavoring agents.

\section{Materials and Methods}

\subsection{Plant Materials}

The Humulus lupulus cultivar "Cascade" was cultivated by Società Agricola s.s. Versil Green (Massarosa, Lucca, Italy). The hop was planted in September 2019 and its growing season started in May 2020 until September 2020, when it was harvested. The plant density was 1 specimen per $\mathrm{m}^{2}$, with plants spaced $100 \mathrm{~cm}$ apart.

The two-row barley cultivars "Tazio" were cultivated by Azienda Agricola Fattoria Le Prata (Pisa, Italy). The sowing was performed in November 2018 with a density of 280-330 specimens per $\mathrm{m}^{2}$. It was harvested in June 2019.

Hibiscus rosa-sinensis (Azienda Agricola Versil Green) plants were grown in pots outdoors and harvested in November 2019.

All the plant material was dried in temperature-controlled stoves, until a constant weight was reached. 


\subsection{Beverages}

\subsubsection{Beer Samples}

The ground grains for this recipe were obtained from 100\% barley malt (Azienda Agricola Le Prata, Pisa, Italy). The mashing process was performed in a multi stage system. The beer style of reference is the American pale ale with a low alcohol content, light body and hoppy character. Once the mixture reached $45^{\circ} \mathrm{C}$, the temperature program proceeded as follows:

(1) $45^{\circ} \mathrm{C}$ for $10 \mathrm{~min}$ (protease enzymes react to hydrolyze low weight protein as nourishment for yeast);

(2) $62{ }^{\circ} \mathrm{C}$ for $20 \mathrm{~min}$ ( $\beta$-amylase activity, $\mathrm{pH} 5.0-5.5$, maximum activity);

(3) $66^{\circ} \mathrm{C}$ for $40 \mathrm{~min}$ ( $\beta$-amylase activity, $\mathrm{pH} 5.0-5.5$, enzymatic synergy point between amylases); and

(4) $78{ }^{\circ} \mathrm{C}$ for $5 \mathrm{~min}$ (enzymatical inactivation phase).

After 15 min of cooling, filtering took place, with washing of the threshes and the collection of the wort in a sanitized fermenter; this process was repeated 6 times, using water at $\mathrm{pH}$ 6. The wort boiling phase was performed for $1 \mathrm{~h}$, together with the addition of bitter and aroma hops. The IBU (International Bitterness Units) value for this recipe was $25 \%$ of $\alpha$ acids. The Cascade hop cones were used for the aroma attributes; they were added in the last $10 \mathrm{~min}$ of the boiling phase to transfer scent and aroma. The wort was then cooled during the whirlpooling phase with a heat exchanger. Dried hibiscus inflorescences were added during this phase, as well. At the same time, an aliquot of wort was cooled separately without adding the hibiscus flowers, in order to obtain the control sample. In the heat exchanger, the hot mash and the coolant (tap water) circulated in counter-current. The mash was then oxygenated to trigger the fermentation, stirring for at least a couple of minutes. Finally, the yeasts (Fermentis SafAle ${ }^{\mathrm{TM}}$ US-05, Lesaffre, Cedex, France) were inoculated and the mix was stirred again. The mix was closed in the fermenter for 12 days at $20^{\circ} \mathrm{C}$, with a gradual temperature decrement down to $4{ }^{\circ} \mathrm{C}$. Subsequently, the bottling and priming processes were carried out. The bottles were stored at $22-25^{\circ} \mathrm{C}$ for 20 days; the nucleation of carbon dioxide was then repeated by placing the bottles in a refrigerator at $4{ }^{\circ} \mathrm{C}$ for $4-5$ days.

\subsubsection{Liqueur Sample}

The hibiscus liqueur was produced with an artisanal method, leaving the hibiscus flowers in infusion in the ethanol obtained from the fermentation of the beer wort. In particular, the production phases were the following:

1. Distillation: a discontinuous distillation was performed to separate the ethyl alcohol from the other desirable substances. This production method is usually used to produce high-end spirits. In this case, the distillation process reached the maximum efficiency of $18-20 \%$.

2. Rectification of the heart of the distilled product: during this phase, the ethyl alcohol undergoes a $2 \%$ reduction. The resulting product was then separated in three fractions: head, heart and tail. The head was eliminated using the first distilled liquid. It presented volatile substances with a lower boiling point than ethanol. The body or heart is the central portion of the product that contains the highest amount of ethyl alcohol and the lowest of impurities. Lastly, the tail was the final part of the product, containing volatile compounds boiling at $\mathrm{T}$ over $100^{\circ} \mathrm{C}$. In the present case, the rectification phase was repeated three times.

3. Addition of hibiscus flowers and maceration: dried hibiscus flowers ( $5 \mathrm{~g} ; 22 \%$ dry weight) were added to the alcoholic solution $(80 \% w / w)$ in a jar, and then left to macerate for 10 days, at $10^{\circ} \mathrm{C}$.

4. Ethanol content reduction and filtering: the exhausted flowers were removed, and the product was filtered. Then, the reduction of the alcoholic title was performed 
with a solution of $50 \mathrm{~g}$ of sugar in $1 \mathrm{~L}$ of distilled water. The cuts of the mixture were performed as below:

- $1 \mathrm{~L}$ alcoholic mixture $(80 \%$ alc. $)+100 \mathrm{~mL}$ cutting mixture $\left(1 \mathrm{~L} \mathrm{H}_{2} \mathrm{O}+50 \mathrm{~g}\right.$ $\mathrm{C}_{6} \mathrm{H}_{12} \mathrm{O}_{6}$ ): $50 \%$ alcoholic title.

- $\quad 50 \%$ alc. $+40 \mathrm{~mL}$ cutting mixture: $38 \%$ alcoholic title.

At the end of each alcoholic cut, the mixture was left to rest in the refrigerator at $4{ }^{\circ} \mathrm{C}$ for $24 \mathrm{~h}$ and filtered with a bacteriology filter to remove any precipitate.

5. Bottling and priming: the alcoholic mixture was then bottled and left in refrigerator to preserve the color from photo-oxidation. After 20 days, a final filtration was performed to remove any precipitates formed following the laagering of the product. The cold allowed the liqueur to refine, reducing the most pungent odors and making the mixture clearer.

\subsection{Phytochemical Investigation}

\subsubsection{Essential Oil Hydrodistillation}

The hydrodistillation of the essential oil from the dried Humulus lupulus L. Cascade cones and $H$. rosa-sinensis L. flowers were performed by a standard Clevenger-type apparatus; the process was protracted for $2 \mathrm{~h}$. The obtained essential oils were diluted to $0.5 \%$ in HPLC-grade $n$-hexane and then injected into a GC-MS apparatus.

\subsubsection{Headspace Solid Phase Microextraction Analysis}

The spontaneous volatile emissions of the dried hop cones and hibiscus flowers, the beer samples, and the hibiscus liqueur were analyzed in triplicates by means of headspace solid phase microextraction (HS-SPME). All the samples ( $2 \mathrm{~g}$ for the plant material and $20 \mathrm{~g}$ for each beer and for the liqueur) were put into a $50 \mathrm{~mL}$ glass flask covered with aluminum foil, and then left to equilibrate at room temperature for $30 \mathrm{~min}$. For all the samples, the adsorption of the volatile compounds of the headspace was performed with a Supelco DVB/CAR/PDMS fiber $(100 \mu \mathrm{m})$ (Supelco analytical, Bellefonte, PA, USA) preconditioned according to the manufacturer instructions. The fiber was exposed to the headspace for $30 \mathrm{~min}$ at room temperature for the hop cones, $60 \mathrm{~min}$ at $40^{\circ} \mathrm{C}$ for $\mathrm{H}$. rosa-sinensis flowers, and $6 \mathrm{~min}$ for the beers, both control (CTR beer) and treated (hibiscus beer), and the liqueur. Once sampling was finished, the fiber was withdrawn into the needle and immediately inserted into the GC-MS apparatus.

\subsubsection{Gas Chromatography-Mass Spectrometry Analyses}

The gas chromatography-electron impact mass spectrometry (GC-EIMS) analyses were performed with an Agilent 7890B gas chromatograph (Agilent Technologies Inc., Santa Clara, CA, USA) equipped with an Agilent HP-5MS capillary column $(30 \mathrm{~m} \times 0.25 \mathrm{~mm}$; coating thickness $0.25 \mu \mathrm{m}$ ) and an Agilent 5977B single quadrupole mass detector. The analytical conditions were set as follows: oven temperature range from 60 to $240{ }^{\circ} \mathrm{C}$ at $3{ }^{\circ} \mathrm{C} / \mathrm{min}$; injector temperature of $220^{\circ} \mathrm{C}$; transfer line temperature of $240^{\circ} \mathrm{C}$; carrier gas helium of $1 \mathrm{~mL} / \mathrm{min}$. The injection volume was $1 \mu \mathrm{L}$, with a split ratio of 1:25. The acquisition parameters were: full scan; scan range: $30-300 \mathrm{~m} / z$; scan time: $1.0 \mathrm{~s}$. The identification of the constituents was based on a comparison of the retention times with those of pure samples, comparing their linear retention indices relative to the series of $n$-hydrocarbons. Computer matching was also used against commercial (NIST 14 and ADAMS 2007) and laboratory-developed mass spectra libraries built up from pure substances and components of commercial essential oils of known composition and MS literature data [23-28].

\subsection{Sensorial Analyses}

\subsubsection{Protocol for Sensory Analysis and Product Presentation}

The sensory analysis of the beers was performed using the Quantitative Descriptive Analysis (QDA) reported by Medoro et. al. [22]. The organoleptic characters of the samples were evaluated by a trained panel of 6 people. The samples were stored in the fridge 
and immediately before tasting, they were poured and served at $10{ }^{\circ} \mathrm{C}$. For the sensorial analysis, the two samples were presented in an $80 \mathrm{~mL}$ glass covered with a glass top and containing $20 \mathrm{~mL}$ of beer per glass. Tests were carried out in individual booths and replicated twice. Water was supplied to rinse the palate between samples.

The two samples were craft beers manufactured by Associazione La Staffetta (located in Calci, Pisa, Italy). Different aromatic features characterized the selected craft beers. The first sample (control) (Figure 1) is an American pale ale (base malt only), with little body and $4.6 \%$ alcoholic content. The second sample (treated) (Figure 2) was produced like the control, but with the addition of dried hibiscus flower at the end of the boiling/whirlpooling phase.

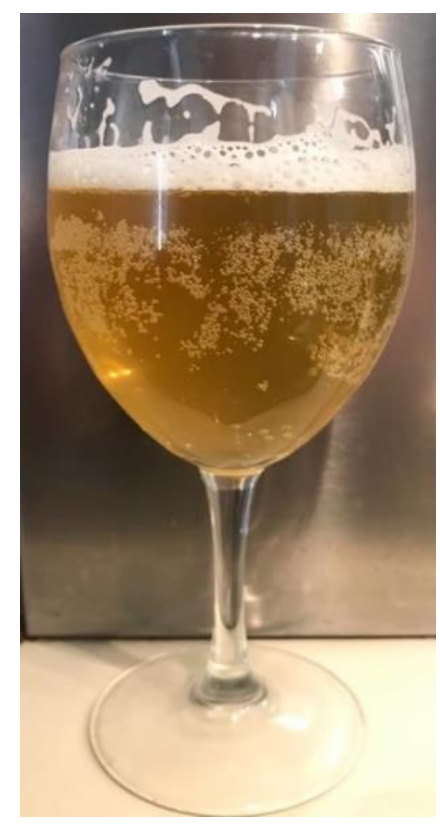

Figure 1. The control beer.

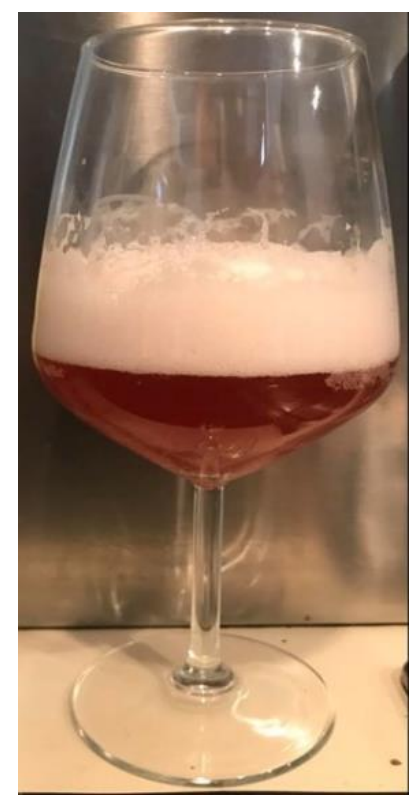

Figure 2. The hibiscus beer. 


\subsubsection{QDA Analysis}

As reported by Medoro et al. [22], 28 attributes (Table 1), derived from literature and from the attribute list used by the "beer taster association" [22] were included in the evaluation process. Nine of them were related to odor, two were visual attributes, fourteen were gustatory traits and three concerned texture (Table 1). The sensory attributes were assessed using an unstructured nine-point, with "absent" and "high" at each scale end.

Table 1. Attribute list used in QDA analysis.

\begin{tabular}{|c|c|}
\hline \multicolumn{2}{|l|}{ Odor Attribute } \\
\hline Overall intensity & Overall odor intensity perceived \\
\hline Malty & $\begin{array}{l}\text { Aromatic note of fermented cereals similar to fresh malt cooked in } \\
\text { the oven }\end{array}$ \\
\hline Hoppy & Typical odor of fresh hop \\
\hline Floral & Aromatic note resembling flowers \\
\hline Fruity & Aromatic note resembling fruits \\
\hline Spicy & Aromatic note resembling spices \\
\hline Honey & Aromatic sweet note resembling honey \\
\hline Roasted & $\begin{array}{l}\text { Aromatic note resembling caramel, bread crust, hazelnuts and } \\
\text { browning of sugars }\end{array}$ \\
\hline \multicolumn{2}{|l|}{ Visual attribute } \\
\hline Foam persistency & Visual persistency of foam in the glass \\
\hline Turbidity & $\begin{array}{l}\text { Presence of suspended particles that confer the beer an opaque } \\
\text { appearance }\end{array}$ \\
\hline \multicolumn{2}{|l|}{ Gustatory attribute } \\
\hline Overall intensity & Overall taste intensity perceived \\
\hline Sweet & Taste of sugar \\
\hline Bitter & Taste of substances such as caffeine or quinine \\
\hline Sour & Taste of acidic substances such as citric acid \\
\hline Alcohol & Flavor sensation of alcohol \\
\hline Malty & Flavor sensation of malt \\
\hline Hoppy & Flavor sensation of hop \\
\hline Floral & Flavor sensation resembling flowers \\
\hline Fruity & Flavor sensation resembling fruits \\
\hline Spicy & Flavor sensation resembling spices \\
\hline Honey & Flavor sensation resembling honey \\
\hline Roasted & $\begin{array}{l}\text { Flavor sensation resembling caramel, bread crust, hazelnuts and } \\
\text { browning of sugars }\end{array}$ \\
\hline \multicolumn{2}{|l|}{ Texture attribute } \\
\hline Fullness & Fullness of beer perceived in mouth \\
\hline Level of carbonation & Attribute resembling the pungency intensity of carbon dioxide \\
\hline Astringency & In-mouth dry sensation \\
\hline
\end{tabular}

\subsection{Biochemical Analyses}

Ground-powdered dried Humulus lupulus L. Cascade cones and Hibiscus rosa-sinensis L. flowers $\left(0.1 \mathrm{~g}\right.$ each) were incubated with $10 \mathrm{~mL}$ of $100 \%$ methanol for $24 \mathrm{~h}$ at $4{ }^{\circ} \mathrm{C}$; thus, the absorbance was read at $665 \mathrm{~nm}, 652 \mathrm{~nm}$ and $470 \mathrm{~nm}$ on a SHIMADZU UV1800 spectrophotometer. Total chlorophylls and carotenoid contents were determined using the proper formulas reported in Lichtenthaler [29]. Biochemical determinations of total monomeric anthocyanins (CAs), total polyphenols (TPs), total flavonoids (TFs) and antioxidant activity were performed on extracts obtained by homogenization of $0.5 \mathrm{~g}$ of the two plant materials with $2 \mathrm{~mL}$ of $70 \%$ aqueous methanol, kept for $30 \mathrm{~min}$ in ice and centrifuged at $14,000 \times g$ for $20 \mathrm{~min}$. The supernatants were used for the biochemical determinations of total monomeric anthocyanins (CAs) total polyphenols (TPs), total flavonoids (TFs) and antioxidant activities. CAs were determined as total monomeric anthocyanin content through the $\mathrm{pH}$ differential method as described by Lee et al. [30] and Giusti and Wrolstad [31]. Samples $(100 \mu \mathrm{L})$ were diluted in aqueous buffer at $\mathrm{pH} 1(0.025 \mathrm{M}$ 
potassium chloride buffer) and $\mathrm{pH} 4.5$ (0.4 M sodium acetate buffer) and the absorbance was read at 510 and $700 \mathrm{~nm}$ in a UV-1800 spectrophotometer (Shimadzu Corporation, Kyoto, Japan). The monomeric anthocyanin pigment concentration was calculated according to the formula reported in Giusti and Wrolstad [31], and the results were expressed as $\mu \mathrm{g}$ of cyanidin-3-O-glucoside (C3G) per gram of FW or DW.

TPs were determined using a modified protocol of the Folin-Ciocalteu method [32]. For plant samples $(5 \mu \mathrm{L})$ and for both the beverages ( $20 \mu \mathrm{L}$ for beer, $10 \mu \mathrm{L}$ for liqueur), the incubation was performed at $40{ }^{\circ} \mathrm{C}$ for $30 \mathrm{~min}$, then the absorbance was spectrophotometrically determined at $765 \mathrm{~nm}$. Total phenolic content (TP) was expressed as $\mathrm{mg} \mathrm{GAE} \mathrm{g}^{-1} \mathrm{DW}$ (mg gallic acid equivalents/g or $\mathrm{mg}$ gallic acid equivalents/per bottle in case of beverages). The total flavonoid content (TF) was determined as reported by Kim et al. [33] in $20 \mu \mathrm{L}$ of plant sample extracts and $50 \mu \mathrm{L}$ of beer and liqueur. The absorbance was read at $510 \mathrm{~nm}$ and the concentration was expressed as mg of (+)-catechin equivalents (CE) per $\mathrm{g}$ of FW or DW and mg gallic acid equivalents/per bottle in the case of a beverage.

\section{Antioxidant Activity}

The antioxidant activity of the different samples was determined by using the 2,2diphenyl-1-picrylhydrazyl radical (DPPH) scavenging method [34]. Aliquots of the methanolic extract $(2,10,20 \mu \mathrm{L})$ were added to $0.25 \mathrm{mM}(w / v)$ DPPH methanol solution to reach a final volume of $1 \mathrm{~mL}$. After $30 \mathrm{~min}$ of incubation at room temperature in the dark, the blenching of DPPH was measured at $517 \mathrm{~nm}$. Trolox was used as a control $(2.5 \mathrm{mM})$. The DPPH scavenging effect $(\%)$ was calculated as $((\mathrm{Abs} 0-\mathrm{Abs} 1 / \mathrm{Abs} 0) \times 100)$, where $\mathrm{Abs} 0$ is the absorbance of the DPPH and Abs1 is the absorbance of the sample.

\subsection{Statistical Analysis}

The dissimilarity contribution percentage of all the compounds of the control beer and the hibiscus beer was assessed by the Similarity Percentage Test (SIMPER) using the Bray-Curtis distance/similarity measure. The statistical significance of the difference in the relative abundances of the compounds accounting for at least $1.00 \%$ in the dissimilarity rate of the emissions was evaluated using the F- or T-test for compounds with equal or unequal variances, respectively. The SIMPER, F- and T-tests were performed with the Past 4.03 Software [35]. Concerning the phytochemical investigation, the analysis of variance (ANOVA) was carried out on the compounds selected with the SIMPER and on the chemical classes, while for the biochemical investigation on the total anthocyanin, total flavonoid and total polyphenol contents, and on the DPPH-assay between the control and the treated beers. The ANOVA analysis was performed using the JMP Pro 13.0.0 software package (SAS Institute, Cary, NC, USA). Averages were separated by Tukey's post hoc test. $p<0.05$ was used to assess the significance of differences between means.

Multivariate statistical analyses were also performed with the JMP software package. The data matrix used for the statistical evaluation of both the EO chemical composition and the headspaces was a $131 \times 6$ covariance matrix $(131$ compounds $\times 6$ samples $=786$ data). The hierarchical cluster analysis (HCA) was performed using Ward's method on non-standardized data, with squared Euclidean distances as a measure of similarity. The principal component analysis (PCA) was performed selecting the two highest PCs, PC1 and PC2, obtained by the linear regression operated on mean-centered, unscaled data, covering $52.6 \%$ and $23.8 \%$ of the variance, respectively, for a total variance of $76.4 \%$.

\section{Results and Discussion}

\subsection{Essential Oils Chemical Composition}

The complete composition and the hydrodistillation yield of the essential oil obtained from the dried cones of $H$. lupulus Cascade are reported in Table 2. Altogether, 49 compounds were identified, accounting for up to $94.4 \%$ of the whole composition. 
Table 2. Chemical composition and extraction yield of the essential oil from the cones of Humulus lupulus L. Cascade.

\begin{tabular}{|c|c|c|c|}
\hline Compounds & 1.r.i ${ }^{1}$ & Class. & $\begin{array}{c}\text { Relative Abundance } \\
(\%) \pm \text { SD }\end{array}$ \\
\hline$\beta$-pinene & 977 & $\mathrm{mh}$ & $0.3 \pm 0.12$ \\
\hline myrcene & 991 & $\mathrm{mh}$ & $15.6 \pm 6.66$ \\
\hline linalool & 1101 & om & $0.1 \pm 0.11$ \\
\hline nonanal & 1105 & nt & $0.1 \pm 0.12$ \\
\hline 2-undecanone & 1294 & nt & $0.3 \pm 0.01$ \\
\hline methyl 4-decenoate & 1312 & nt & $0.6 \pm 0.05$ \\
\hline methyl geranate & 1324 & om & $0.5 \pm 0.10$ \\
\hline$\alpha$-copaene & 1376 & $\mathrm{sh}$ & $0.3 \pm 0.00$ \\
\hline geranyl acetate & 1385 & om & $0.4 \pm 0.04$ \\
\hline$\beta$-caryophyllene & 1419 & $\mathrm{sh}$ & $9.0 \pm 0.03$ \\
\hline$\beta$-copaene & 1429 & $\mathrm{sh}$ & $0.1 \pm 0.10$ \\
\hline trans- $\alpha$-bergamotene & 1436 & sh & $0.3 \pm 0.02$ \\
\hline$\alpha$-humulene & 1453 & $\mathrm{sh}$ & $28.9 \pm 0.04$ \\
\hline$(E)$ - $\beta$-farnesene & 1458 & sh & $3.8 \pm 0.12$ \\
\hline trans-cadina-1(6),4-diene & 1474 & sh & $0.2 \pm 0.06$ \\
\hline$\beta$-chamigrene & 1485 & sh & $0.5 \pm 0.17$ \\
\hline$\gamma$-muurolene & 1477 & sh & $1.0 \pm 0.08$ \\
\hline$\alpha$-amorphene & 1482 & $\mathrm{sh}$ & $0.2 \pm 0.00$ \\
\hline$\beta$-selinene & 1486 & sh & $2.2 \pm 0.26$ \\
\hline$\alpha$-selinene & 1495 & $\mathrm{sh}$ & $2.3 \pm 0.27$ \\
\hline 2-tridecanone & 1496 & nt & $0.8 \pm 0.19$ \\
\hline epizonarene & 1500 & $\mathrm{sh}$ & $0.2 \pm 0.02$ \\
\hline$\alpha$-muurolene & 1501 & sh & $0.4 \pm 0.07$ \\
\hline$(E, E)$ - $\alpha$-farnesene & 1509 & sh & $0.4 \pm 0.06$ \\
\hline trans- $\gamma$-cadinene & 1514 & sh & $1.8 \pm 0.24$ \\
\hline$\delta$-cadinene & 1524 & sh & $2.8 \pm 0.26$ \\
\hline cubenene & 1533 & sh & $0.2 \pm 0.02$ \\
\hline$\alpha$-cadinene & 1537 & sh & $0.2 \pm 0.04$ \\
\hline$\alpha$-calacorene & 1543 & $\mathrm{sh}$ & $0.2 \pm 0.04$ \\
\hline elemol & 1550 & os & $0.2 \pm 0.07$ \\
\hline caryophyllene alcohol & 1563 & os & $0.3 \pm 0.01$ \\
\hline caryophyllene oxide & 1582 & os & $1.7 \pm 0.33$ \\
\hline isoaromadendrene epoxide & 1586 & os & $1.5 \pm 0.31$ \\
\hline epi-globulol & 1590 & os & $0.3 \pm 0.33$ \\
\hline humulene oxide II & 1608 & os & $5.2 \pm 0.99$ \\
\hline humulane-1-6-dien-3-ol & 1613 & os & $0.3 \pm 0.12$ \\
\hline 1,10-di-epi-cubenol & 1615 & os & $0.2 \pm 0.05$ \\
\hline 1-epi-cubenol & 1627 & os & $1.2 \pm 0.26$ \\
\hline caryophylla-4(14),8(15)-dien-5-ol & 1633 & os & $0.7 \pm 0.15$ \\
\hline T-cadinol & 1641 & os & $1.4 \pm 0.22$ \\
\hline T-muurolol & 1646 & os & $0.2 \pm 0.05$ \\
\hline$\alpha$-cadinol & 1654 & os & $1.5 \pm 0.18$ \\
\hline 14-hydroxy-9-epi-(E)-caryophyllene & 1665 & os & $1.0 \pm 0.24$ \\
\hline aromadendrene epoxide II & 1680 & os & $0.6 \pm 0.08$ \\
\hline 2-pentadecanone & 1699 & nt & $0.2 \pm 0.04$ \\
\hline$(E, E)$-farnesol & 1723 & os & $0.5 \pm 0.10$ \\
\hline$m$-camphorene & 1952 & $\mathrm{dh}$ & $0.3 \pm 0.03$ \\
\hline hexadecanoic acid & 1963 & $\mathrm{nt}$ & $3.1 \pm 0.36$ \\
\hline phytol & 2112 & od & $0.3 \pm 0.02$ \\
\hline Total identified (\%) & & & $94.4 \pm 1.03$ \\
\hline
\end{tabular}


Table 2. Cont.

\begin{tabular}{|c|c|c|}
\hline Compounds & Class. & $\begin{array}{c}\text { Relative Abundance } \\
(\%) \pm \text { SD }\end{array}$ \\
\hline Monoterpene hydrocarbons (mh) & & $16.0 \pm 6.78$ \\
\hline Oxygenated monoterpenes (om) & & $1.0 \pm 0.03$ \\
\hline Sesquiterpene hydrocarbons (sh) & & $55.2 \pm 1.82$ \\
\hline Oxygenated sesquiterpenes (os) & & $16.7 \pm 3.48$ \\
\hline Diterpene hydrocarbons (dh) & & $0.3 \pm 0.03$ \\
\hline Oxygenated diterpenes (od) & & $0.3 \pm 0.02$ \\
\hline Other non-terpene derivates (nt) & & $5.0 \pm 0.40$ \\
\hline EO hydrodistillation yield ( $\% w / w)$ & & $0.3 \pm 0.04$ \\
\hline
\end{tabular}

${ }^{1}$ Linear retention index on a HP 5-MS capillary column.

Sesquiterpenes were the most represented chemical class of compounds in both their hydrocarbons and oxygenated derivatives, which reached $55.2 \%$ and $16.7 \%$, respectively. $\alpha$-humulene (28.9\%), $\beta$-caryophyllene $(9.0 \%)$ and $(E)$ - $\beta$-farnesene $(3.8 \%)$ were the main chemicals belonging to the hydrocarbon form, and humulene oxide II (5.2\%) to the oxygenated one. Monoterpenes were also quantitatively well represented, but almost only in their hydrocarbon form $(16.0 \%)$. Among this class, only two volatile compounds were identified, but myrcene was the predominant, as it accounted for up to $15.6 \%$.

Nance et al. [36] and Forteschi et al. [37] reported the same major chemical constituent identified in the present work, but they highlighted a predominance of monoterpenes as the main chemical class in the EOs obtained from Cascade hops.

No essential oil was obtained from the hydrodistillation of the Hibiscus rosa-sinensis L. flowers.

\subsection{Headspaces Chemical Composition}

\subsubsection{Plant Materials}

The complete composition of the headspaces (HSs) of the starting plant materials, represented by H. lupulus Cascade cones and H. rosa-sinensis flowers, is reported in Table 3. A total of 77 compounds were identified, covering $99.5 \%$ and $99.7 \%$ of the complete compositions, respectively.

Table 3. Chemical composition of the headspaces of Humulus lupulus L. Cascade cones and Hibiscus rosa-sinensis L. flowers.

\begin{tabular}{|c|c|c|c|c|}
\hline \multirow{2}{*}{ Compounds } & \multirow{2}{*}{ 1.r.i. ${ }^{1}$} & \multirow{2}{*}{ Class. } & \multicolumn{2}{|c|}{ Relative Abundance (\%) \pm SD } \\
\hline & & & SPME Hop & SPME Hibiscus \\
\hline acetic acid & 603 & $\mathrm{nt}$ & -2 & $2.0 \pm 0.06$ \\
\hline 2-methylbutanal & 659 & nt & - & $0.1 \pm 0.01$ \\
\hline pentanal & 699 & nt & - & $0.3 \pm 0.06$ \\
\hline prenol & 775 & nt & $0.1 \pm 0.01$ & - \\
\hline 1,3-butanediol & 778 & nt & - & $2.7 \pm 0.36$ \\
\hline prenal & 782 & nt & $0.1 \pm 0.02$ & - \\
\hline hexanal & 809 & nt & - & $2.4 \pm 0.07$ \\
\hline 2,3-butanediol & 843 & nt & - & $5.6 \pm 0.30$ \\
\hline 1-hexanol & 903 & nt & - & $0.8 \pm 0.11$ \\
\hline heptanal & 907 & nt & - & $1.3 \pm 0.08$ \\
\hline isobutyl isobutyrate & 910 & nt & $0.1 \pm 0.01$ & - \\
\hline methyl hexanoate & 925 & nt & $0.3 \pm 0.01$ & - \\
\hline$\alpha$-pinene & 933 & $\mathrm{mh}$ & $0.6 \pm 0.04$ & $1.7 \pm 0.04$ \\
\hline benzaldheyde & 959 & nt & - & $0.3 \pm 0.00$ \\
\hline pentyl propanoate & 969 & nt & $0.5 \pm 0.07$ & - \\
\hline hexanoic acid & 979 & nt & - & $0.3 \pm 0.13$ \\
\hline
\end{tabular}


Table 3. Cont.

\begin{tabular}{|c|c|c|c|c|}
\hline \multirow{2}{*}{ Compounds } & \multirow{2}{*}{ 1.r.i. ${ }^{1}$} & \multirow{2}{*}{ Class. } & \multicolumn{2}{|c|}{ Relative Abundance (\%) \pm SD } \\
\hline & & & SPME Hop & SPME Hibiscus \\
\hline$\beta$-pinene & 977 & $\mathrm{mh}$ & $2.7 \pm 0.07$ & $0.5 \pm 0.12$ \\
\hline 6-methyl-5-hepten-2-one & 986 & nt & - & $1.0 \pm 0.07$ \\
\hline myrcene & 991 & $\mathrm{mh}$ & $64.9 \pm 2.19$ & $1.2 \pm 0.06$ \\
\hline octanal & 1003 & nt & - & $0.9 \pm 0.05$ \\
\hline$\alpha$-phellandrene & 1006 & $\mathrm{mh}$ & $0.1 \pm 0.02$ & - \\
\hline isoamyl isobutanoate & 1015 & nt & $0.3 \pm 0.04$ & - \\
\hline 2-metylbutyl isobutyrate & 1016 & nt & $0.5 \pm 0.06$ & - \\
\hline$\alpha$-terpinene & 1017 & $\mathrm{mh}$ & $0.1 \pm 0.01$ & - \\
\hline methyl heptanoate & 1023 & nt & $0.7 \pm 0.02$ & - \\
\hline$p$-cymene & 1025 & $\mathrm{mh}$ & - & $2.1 \pm 0.33$ \\
\hline 3-ethyl-1-hexanol & 1027 & nt & - & $1.0 \pm 0.20$ \\
\hline limonene & 1029 & $\mathrm{mh}$ & $2.1 \pm 0.09$ & $2.4 \pm 0.35$ \\
\hline 1,8-cineole & 1031 & om & - & $19.1 \pm 2.67$ \\
\hline (Z)- $\beta$-ocimene & 1036 & $\mathrm{mh}$ & $0.2 \pm 0.02$ & - \\
\hline phenylacetaldehyde & 1043 & nt & - & $0.4 \pm 0.04$ \\
\hline (E)- $\beta$-ocimene & 1047 & $\mathrm{mh}$ & $0.8 \pm 0.05$ & - \\
\hline$\gamma$-terpinene & 1058 & $\mathrm{mh}$ & $0.1 \pm 0.00$ & $0.6 \pm 0.15$ \\
\hline 1-octanol & 1069 & nt & - & $0.3 \pm 0.07$ \\
\hline 2,3,5,6-tetramethyl pyrazine & 1088 & pyr & - & $0.6 \pm 0.02$ \\
\hline 2-nonanone & 1092 & nt & $0.2 \pm 0.01$ & $0.2 \pm 0.03$ \\
\hline linalool & 1101 & om & $0.5 \pm 0.03$ & $1.1 \pm 0.02$ \\
\hline nonanal & 1105 & nt & - & $3.3 \pm 0.17$ \\
\hline phenylethyl alcohol & 1114 & nt & - & $0.7 \pm 0.09$ \\
\hline methyl octanoate & 1129 & nt & $0.3 \pm 0.02$ & - \\
\hline camphor & 1145 & om & - & $0.4 \pm 0.12$ \\
\hline citronellal & 1153 & om & - & $0.5 \pm 0.01$ \\
\hline borneol & 1165 & om & - & $0.6 \pm 0.07$ \\
\hline menthol & 1173 & om & - & $1.0 \pm 0.04$ \\
\hline 4-terpineol & 1177 & om & - & $1.1 \pm 0.13$ \\
\hline$\alpha$-terpineol & 1191 & om & - & $1.2 \pm 0.17$ \\
\hline decanal & 1206 & nt & - & $1.1 \pm 0.13$ \\
\hline carvone & 1244 & om & - & $0.8 \pm 0.11$ \\
\hline nonanoic acid & 1269 & nt & - & $0.8 \pm 0.13$ \\
\hline thymol & 1292 & om & - & $0.3 \pm 0.04$ \\
\hline 2-undecanone & 1294 & nt & $0.1 \pm 0.00$ & - \\
\hline carvacrol & 1302 & om & - & $1.2 \pm 0.04$ \\
\hline methyl 4-decenoate & 1312 & $\mathrm{nt}$ & $0.3 \pm 0.03$ & - \\
\hline methyl geranate & 1324 & om & $0.2 \pm 0.02$ & - \\
\hline$\alpha$-terpinyl acetate & 1350 & om & - & $0.9 \pm 0.08$ \\
\hline neryl acetate & 1365 & om & - & $0.6 \pm 0.08$ \\
\hline$\alpha$-ylangene & 1372 & $\mathrm{sh}$ & $0.2 \pm 0.03$ & - \\
\hline$\alpha$-copaene & 1376 & $\mathrm{sh}$ & $0.6 \pm 0.08$ & $0.3 \pm 0.05$ \\
\hline$\beta$-caryophyllene & 1419 & sh & $6.6 \pm 0.32$ & $7.5 \pm 0.61$ \\
\hline$\beta$-copaene & 1429 & sh & $0.2 \pm 0.02$ & - \\
\hline trans- $\alpha$-bergamotene & 1436 & $\mathrm{sh}$ & $0.3 \pm 0.03$ & $0.7 \pm 0.11$ \\
\hline aromadendrene & 1442 & sh & - & $0.4 \pm 0.11$ \\
\hline$\alpha$-humulene & 1453 & sh & $12.0 \pm 1.39$ & $10.1 \pm 0.78$ \\
\hline (E)- $\beta$-farnesene & 1458 & sh & $1.5 \pm 0.08$ & $2.6 \pm 0.00$ \\
\hline$\gamma$-muurolene & 1477 & sh & $0.3 \pm 0.03$ & $0.7 \pm 0.06$ \\
\hline$\beta$-selinene & 1486 & $\mathrm{sh}$ & $0.6 \pm 0.04$ & $1.4 \pm 0.07$ \\
\hline$\alpha$-selinene & 1495 & $\mathrm{sh}$ & $0.7 \pm 0.08$ & $1.1 \pm 0.01$ \\
\hline$\alpha$-muurolene & 1500 & sh & $0.1 \pm 0.05$ & $0.3 \pm 0.04$ \\
\hline$\beta$-bisabolene & 1509 & sh & - & $0.1 \pm 0.01$ \\
\hline
\end{tabular}


Table 3. Cont.

\begin{tabular}{|c|c|c|c|c|}
\hline \multirow{2}{*}{ Compounds } & \multirow{2}{*}{ 1.r.i. ${ }^{1}$} & \multirow{2}{*}{ Class. } & \multicolumn{2}{|c|}{ Relative Abundance $(\%) \pm$ SD } \\
\hline & & & SPME Hop & SPME Hibiscus \\
\hline trans- $\gamma$-cadinene & 1514 & sh & $0.3 \pm 0.04$ & $0.9 \pm 0.11$ \\
\hline$\delta$-cadinene & 1524 & sh & $0.4 \pm 0.12$ & $1.9 \pm 0.26$ \\
\hline$\alpha$-cadinene & 1537 & sh & - & $0.4 \pm 0.03$ \\
\hline spathulenol & 1577 & os & - & $1.0 \pm 0.02$ \\
\hline caryophyllene oxide & 1582 & os & - & $1.0 \pm 0.06$ \\
\hline humulene oxide II & 1608 & os & - & $0.9 \pm 0.02$ \\
\hline$\gamma$-eudesmol & 1631 & os & - & $0.2 \pm 0.01$ \\
\hline hexahydrofarnesylacetone & 1845 & ac & - & $4.9 \pm 0.23$ \\
\hline Total identified (\%) & & & $99.5 \pm 0.05$ & $99.7 \pm 0.03$ \\
\hline Monoterpene hydrocarbons (mh) & & & $71.6 \pm 2.2$ & $8.4 \pm 0.73$ \\
\hline Oxygenates monoterpenes (om) & & & $0.7 \pm 0.05$ & $28.7 \pm 1.98$ \\
\hline Sesquiterpene hydrocarbons (sh) & & & $23.7 \pm 2.14$ & $28.6 \pm 2.21$ \\
\hline Oxygenated sesquiterpens (os) & & & - & $3.0 \pm 0.01$ \\
\hline Apocarotenoids (ac) & & & - & $4.9 \pm 0.23$ \\
\hline Pyrazine (pyr) & & & - & $0.6 \pm 0.02$ \\
\hline Other non-terpene derivates (nt) & & & $3.5 \pm 0.03$ & $25.4 \pm 0.75$ \\
\hline
\end{tabular}

${ }^{1}$ Linear retention index on a HP 5-MS capillary column. ${ }^{2}$ Not detected.

The volatilome of the hop cones was characterized by a predominance of terpenes in their hydrocarbon form. In particular, monoterpene hydrocarbons were the most abundant chemical class, as they accounted up for $71.6 \%$, followed by sesquiterpene hydrocarbons, which represented $23.7 \%$ of the whole headspace composition. Among the former class, myrcene $(64.9 \%)$ was the main detected chemical, whilst among the latter, $\alpha$-humulene $(12.0 \%), \beta$-caryophyllene (6.6\%) and (E)- $\beta$-farnesene $(1.5 \%)$ were predominant, confirming what has been previously reported $[36,37]$.

In the headspace of the hibiscus flowers, both terpenes and non-terpene derivatives were well represented. Among terpenes, oxygenated monoterpenes and sesquiterpene hydrocarbons were revealed in comparable relative amounts, as they constituted $28.7 \%$ and $28.6 \%$ of the total volatilome, respectively. 1,8 -Cineole $(19.1 \%), \alpha$-humulene $(10.1 \%)$ and $\beta$-caryophyllene $(7.5 \%)$, were the main chemicals of these classes. Non-terpene derivatives represented $25.4 \%$ of the HS composition, and 2,3-butanediol (5.6\%) was the compound detected in the highest relative abundance.

\subsubsection{Beverages}

Beer Sample

The complete composition of the HSs of the beer samples, both the control and the treated beers, is reported in Table 4 . A total of 23 compounds were identified, covering $100.0 \%$ and $99.9 \%$ of the total composition, respectively. 
Table 4. Chemical composition of the headspaces of the beer samples.

\begin{tabular}{|c|c|c|c|c|}
\hline \multirow{2}{*}{ Compounds } & \multirow{2}{*}{ 1.r.i. ${ }^{1}$} & \multirow{2}{*}{ Class. } & \multicolumn{2}{|c|}{ Relative Abundance $(\%) \pm$ SD } \\
\hline & & & CTR Beer & Hibiscus Beer \\
\hline acetic acid & 603 & nt & $4.9 \pm 0.39^{a}$ & $-3, b$ \\
\hline ethyl acetate & 743 & nt & $14.6 \pm 1.36^{b}$ & $30.4 \pm 3.11^{\mathrm{a}}$ \\
\hline isoamyl alcohol & 736 & nt & $15.5 \pm 1.47$ & $13.7 \pm 1.54$ \\
\hline 2-methylbutanol & 737 & nt & $4.4 \pm 0.23$ & $4.4 \pm 0.68$ \\
\hline 1-pentanol & 765 & nt & $0.1 \pm 0.00$ & - \\
\hline isobutyl acetate & 771 & nt & $0.9 \pm 0.06$ & $0.7 \pm 0.10$ \\
\hline ethyl butyrate & 862 & nt & $1.6 \pm 0.12^{a}$ & $1.1 \pm 0.08^{b}$ \\
\hline isopentyl acetate & 876 & nt & $7.7 \pm 0.55^{b}$ & $10.6 \pm 0.28^{\mathrm{a}}$ \\
\hline 2-methylbutanol acetate & 880 & nt & $1.2 \pm 0.04$ & $1.0 \pm 0.17$ \\
\hline styrene & 893 & nt & $2.1 \pm 0.07$ & $2.2 \pm 0.88$ \\
\hline myrcene & 991 & $\mathbf{m h}$ & $2.2 \pm 0.30^{\mathrm{a}}$ & $0.5 \pm 0.27^{b}$ \\
\hline ethyl hexanoate & 998 & nt & $8.6 \pm 0.40^{a}$ & $7.0 \pm 0.23^{b}$ \\
\hline ethyl heptanoate & 1101 & nt & $0.3 \pm 0.06$ & $0.2 \pm 0.06$ \\
\hline nonanal & 1105 & nt & $0.1 \pm 0.21$ & $0.1 \pm 0.03$ \\
\hline phenylethyl alcohol & 1114 & nt & $0.9 \pm 0.19$ & $0.7 \pm 0.04$ \\
\hline ethyl octanoate & 1199 & nt & $26.4 \pm 1.14^{a}$ & $21.4 \pm 1.89^{b}$ \\
\hline decanal & 1206 & nt & - & $0.2 \pm 0.03$ \\
\hline 2-phenylethyl acetate & 1257 & nt & $0.1 \pm 0.01$ & - \\
\hline ethyl nonanoate & 1296 & nt & $0.1 \pm 0.01$ & $0.1 \pm 0.02$ \\
\hline ethyl 9-decenoate & 1387 & nt & $1.3 \pm 0.16$ & $1.2 \pm 0.12$ \\
\hline ethyl decanoate & 1396 & nt & $5.5 \pm 1.27$ & $3.9 \pm 0.68$ \\
\hline$\beta$-caryophyllene & 1419 & sh & $0.2 \pm 0.10$ & - \\
\hline$\alpha$-humulene & 1453 & sh & $1.1 \pm 0.42^{a}$ & $0.3 \pm 0.15^{b}$ \\
\hline Total identified (\%) & & & $100.0 \pm 0.01$ & $99.9 \pm 0.04$ \\
\hline $\begin{array}{l}\text { Monoterpenes } \\
\text { hydrocarbons (mh) }\end{array}$ & & & $2.1 \pm 0.14^{\mathrm{a}}$ & $0.5 \pm 0.27^{b}$ \\
\hline $\begin{array}{l}\text { Sesquiterpene } \\
\text { hydrocarbons (sh) }\end{array}$ & & & $1.4 \pm 0.52^{\mathrm{a}}$ & $0.3 \pm 0.15^{b}$ \\
\hline $\begin{array}{l}\text { Other non-terpene } \\
\text { derivatives (nt) }\end{array}$ & & & $96.4 \pm 0.80^{b}$ & $99.0 \pm 0.41^{\mathrm{a}}$ \\
\hline Acids & & & $4.9 \pm 0.39^{\mathrm{a}}$ & $-b$ \\
\hline Alcohols & & & $20.9 \pm 1.28$ & $18.8 \pm 2.19$ \\
\hline Esters & & & $68.4 \pm 0.51^{\mathrm{b}}$ & $77.6 \pm 1.13^{\mathrm{a}}$ \\
\hline Aldehydes & & & $0.1 \pm 0.21$ & $0.3 \pm 0.03$ \\
\hline Hydrocarbons & & & $2.1 \pm 0.07$ & $2.2 \pm 0.88$ \\
\hline
\end{tabular}

${ }^{1}$ Linear retention index on a HP 5-MS capillary column. ${ }^{2}$ Compounds accounting for at least $1.000 \%$ of the dissimilarity contribution, assessed by the SIMPER test, are evidenced in bold. For these compounds and for the chemical classes, the superscript lowercase letters $(a, b)$ indicate statistically significant differences between the control and the treated beers. The statistical significance of the relative abundances was determined by Tukey's post hoc test, with $p \leq 0.05 .{ }^{3}$ Not detected.

Undoubtedly, non-terpene derivatives constituted the main class of components of the aroma of both the samples, representing $96.4 \%$ of the whole volatilome in the control beer and $99.0 \%$ in the hibiscus one. Within this chemical class, esters were the most abundant compounds, being significantly higher in the treated sample (77.6\%) than in the control $(68.4 \%)$. Ethyl acetate, isopentyl acetate, ethyl hexanoate, ethyl octanoate and ethyl decanoate were the most represented volatiles. Esters are considered the main chemical class contributing to beer aromas and flavors [12], as they are responsible for fruity and flowery notes, even if in small amounts, thanks to their low odor threshold [12,38]. In particular, isopentyl acetate, which confer sweet, banana flavor characters, is a desirable acetate ester derivatives originating from the yeast metabolism [39]. However, high amounts of this VOC are related to high content of ethyl acetate, which, instead, presents solvent-like scents. Ethyl hexanoate, ethyl octanoate and ethyl decanoate are aliphatic esters relevant for the beer aroma: the first two confer apple-like notes, whilst the latter is responsible 
for pear-like hints [39]. Alcohols were also detected in appreciable relative amounts in both beers, accounting for up to $20.9 \%$ in the CTR beer and $18.8 \%$ in the hibiscus beer. However, there was no relevant qualitative variability within this chemical group, as only four volatile organic compounds (VOCs) were identified, of which only isoamyl alcohol $(\mathrm{CTR}=15.5 \%$; Hibiscus $=13.7 \%)$ and 2-methylbutanol $($ amyl alcohol $)($ both $4.4 \%)$ were detected in substantial amounts. Higher alcohols, together with esters, are among the major chemical classes responsible for fruity and floral notes in beer aromas. Isoamyl alcohol, as isopentyl acetate, presented banana characters, and its impact on the beer flavor is significantly incremented by the presence of 2-methylbutanol, which has similar sensorial attributes [39]. Acids, represented only by acetic acid, were detected only in the control beer, in which they reached $4.9 \%$ of the whole composition. The presence of high relative content of acetic acid is undesirable, as it is responsible for sour and pungent vinegar-like off-flavors [38], although lower relative concentrations of this compound can be appreciated as conferring a peculiar acidic after-taste.

In addition to non-terpenes, some terpenes derivatives were detected, even if in low relative amounts. These compounds positively affect the beer aromas and flavor, since they confer spicy and citrus hints to the product [38]. Myrcene (monoterpene hydrocarbon) and $\alpha$-humulene (sesquiterpene hydrocarbon), both characteristic compounds of the hop EO [10], were identified in both samples, but they were significantly higher in the control beer $(2.2 \%$ and $1.1 \%$, respectively), than in the treated one $(0.5 \%$ and $0.3 \%$, respectively).

\section{Liqueur Sample}

The complete composition of the HS of the hibiscus liqueur is reported in Table 5. Overall, 34 compounds were identified, representing $100.0 \%$ of the total composition.

Table 5. Chemical composition of the hibiscus liqueur headspace.

\begin{tabular}{|c|c|c|c|}
\hline Compounds & 1.r.i. ${ }^{1}$ & Class. & $\begin{array}{l}\text { Relative Abundance } \\
(\%) \pm \text { SD }\end{array}$ \\
\hline ethyl acetate & 743 & nt & $1.7 \pm 0.02$ \\
\hline isoamyl alcohol & 736 & nt & $1.7 \pm 0.05$ \\
\hline 2-methylbutanol & 737 & nt & $1.0 \pm 0.02$ \\
\hline isopentyl acetate & 876 & nt & $1.5 \pm 0.07$ \\
\hline$\alpha$-thujene & 926 & $\mathrm{mh}$ & $1.4 \pm 0.11$ \\
\hline$\alpha$-pinene & 933 & $\mathrm{mh}$ & $13.0 \pm 0.57$ \\
\hline camphene & 948 & $\mathrm{mh}$ & $0.5 \pm 0.03$ \\
\hline sabinene & 973 & $\mathrm{mh}$ & $4.3 \pm 0.10$ \\
\hline$\beta$-pinene & 977 & $\mathrm{mh}$ & $7.5 \pm 0.23$ \\
\hline myrcene & 991 & $\mathrm{mh}$ & $9.4 \pm 0.08$ \\
\hline$\alpha$-terpinene & 1017 & $\mathrm{mh}$ & $0.8 \pm 0.07$ \\
\hline p-cymene & 1025 & $\mathrm{mh}$ & $10.2 \pm 0.16$ \\
\hline limonene & 1029 & $\mathrm{mh}$ & $34.4 \pm 0.04$ \\
\hline 1,8-cineole & 1031 & om & $0.3 \pm 0.04$ \\
\hline$\gamma$-terpinene & 1058 & $\mathrm{mh}$ & $4.1 \pm 0.01$ \\
\hline terpinolene & 1089 & $\mathrm{mh}$ & $0.9 \pm 0.02$ \\
\hline ethyl octanoate & 1199 & nt & $0.8 \pm 0.10$ \\
\hline 2-phenylethyl acetate & 1257 & nt & $0.2 \pm 0.03$ \\
\hline$(E, Z)$-2,4-decadienal & 1293 & nt & $0.2 \pm 0.04$ \\
\hline$(E, E)-2,4$-decadienal & 1316 & nt & $0.6 \pm 0.13$ \\
\hline$\alpha$-cubebene & 1350 & $\mathrm{sh}$ & $0.4 \pm 0.05$ \\
\hline$\alpha$-copaene & 1376 & $\mathrm{sh}$ & $0.1 \pm 0.02$ \\
\hline$\beta$-elemene & 1392 & $\mathrm{sh}$ & $0.4 \pm 0.07$ \\
\hline ethyl decanoate & 1396 & nt & $0.6 \pm 0.10$ \\
\hline$\beta$-caryophyllene & 1419 & sh & $1.2 \pm 0.17$ \\
\hline$\gamma$-elemene & 1433 & sh & $0.5 \pm 0.07$ \\
\hline
\end{tabular}


Table 5. Cont.

\begin{tabular}{lccc}
\hline Compounds & 1.r.i. ${ }^{\mathbf{1}}$ & Class. & $\begin{array}{c}\text { Relative Abundance } \\
\text { (\%) } \pm \text { SD }\end{array}$ \\
\hline trans- $\alpha$-bergamotene & 1436 & sh & $0.4 \pm 0.06$ \\
$\alpha$-humulene & 1453 & sh & $0.5 \pm 0.07$ \\
(E)- $\beta$-farnesene & 1458 & sh & $0.2 \pm 0.03$ \\
germacrene D & 1481 & sh & $0.3 \pm 0.05$ \\
$\beta$-selinene & 1486 & sh & $0.1 \pm 0.00$ \\
$\beta$-bisabolene & 1509 & sh & $0.3 \pm 0.04$ \\
S-cadinene & 1524 & sh & $0.3 \pm 0.05$ \\
ethyl dodecanoate & 1596 & nt & $0.2 \pm 0.02$ \\
\hline Total identified (\%) & & & $100.0 \pm 0.01$ \\
\hline Monoterpene hydrocarbons (mh) & & & $86.3 \pm 0.96$ \\
Oxygenated monoterpenes (om) & & & $0.3 \pm 0.04$ \\
Sesquiterpene hydrocarbons (sh) & & & $4.8 \pm 0.69$ \\
Other non-terpene derivatives (nt) & & & $8.5 \pm 0.29$ \\
Alcohols & & & $2.7 \pm 0.06$ \\
Esters & & & $4.9 \pm 0.15$ \\
Aldehydes & & $0.8 \pm 0.15$ \\
\hline
\end{tabular}

${ }^{1}$ Linear retention index on a HP 5-MS capillary column.

Monoterpene hydrocarbons were the main class of VOCs determining the aroma of the hibiscus liqueur, as they reached $86.3 \%$ of the whole chemical profile: among these, limonene $(34.4 \%), \alpha$-pinene $(13.0 \%)$, p-cymene $(10.2 \%)$, myrcene $(9.4 \%)$, and $\beta$ pinene $(7.5 \%)$ were the main components. On the contrary, oxygenated monoterpenes were detected in negligible relative amounts $(0.3 \%)$. Sesquiterpene hydrocarbons were also well represented in the sample, accounting up for $4.8 \%$ of the volatilome. In total, 12 compounds belonging to this class were identified, but only $\beta$-caryophyllene was revealed in appreciable relative abundance $(1.2 \%)$. Finally, non-terpene derivatives were the second relevant chemical class characterizing the liqueur aroma (8.5\%). Among these, esters and alcohols were the most represented as they reached $4.9 \%$ and $2.7 \%$, respectively.

\subsection{Multivariate Statistical Analysis}

The dendrogram obtained by the hierarchical cluster analysis (HCA), performed on the complete chemical composition of the Cascade hop EO and the HSs of the starting plant materials and the beverages (Figure 3), evidenced a partition of the samples in two macrocluster. The hop HS (SPME Hop) was clustered by itself in the pink group, confirming the chemical differences with all the other samples. The second cluster was further divided into two sub-groups, green and blue, whose samples presented a composition closer to each other than to the pink sample. The green cluster comprises the hop EO and the HS of the hibiscus flowers (SPME Hibiscus), clustered together in a further sub-group, and the HS of the hibiscus liqueur (SPME Hibiscus Liqueur). The HSs of the two beer samples (SPME CTR Beer and SPME Hibiscus Beer) were clustered in the blue group, evidencing the compositional similarity reported by the GC-MS analysis.

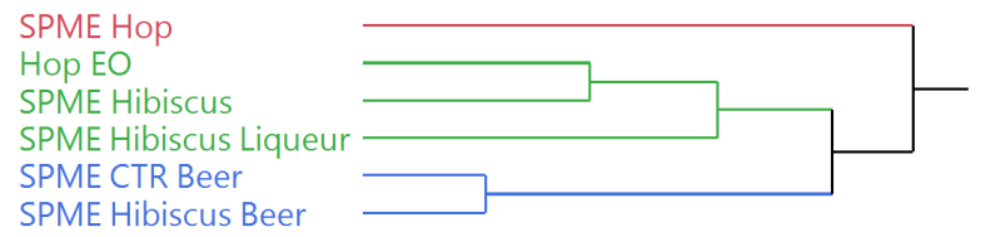

Figure 3. Dendrogram of the hierarchical cluster analysis (HCA) performed on the complete composition of the Cascade hop EO and the headspaces of the plant materials and the beverages. 
The score and the loading plots of the principal component analysis (PCA) are reported in Figure 4.
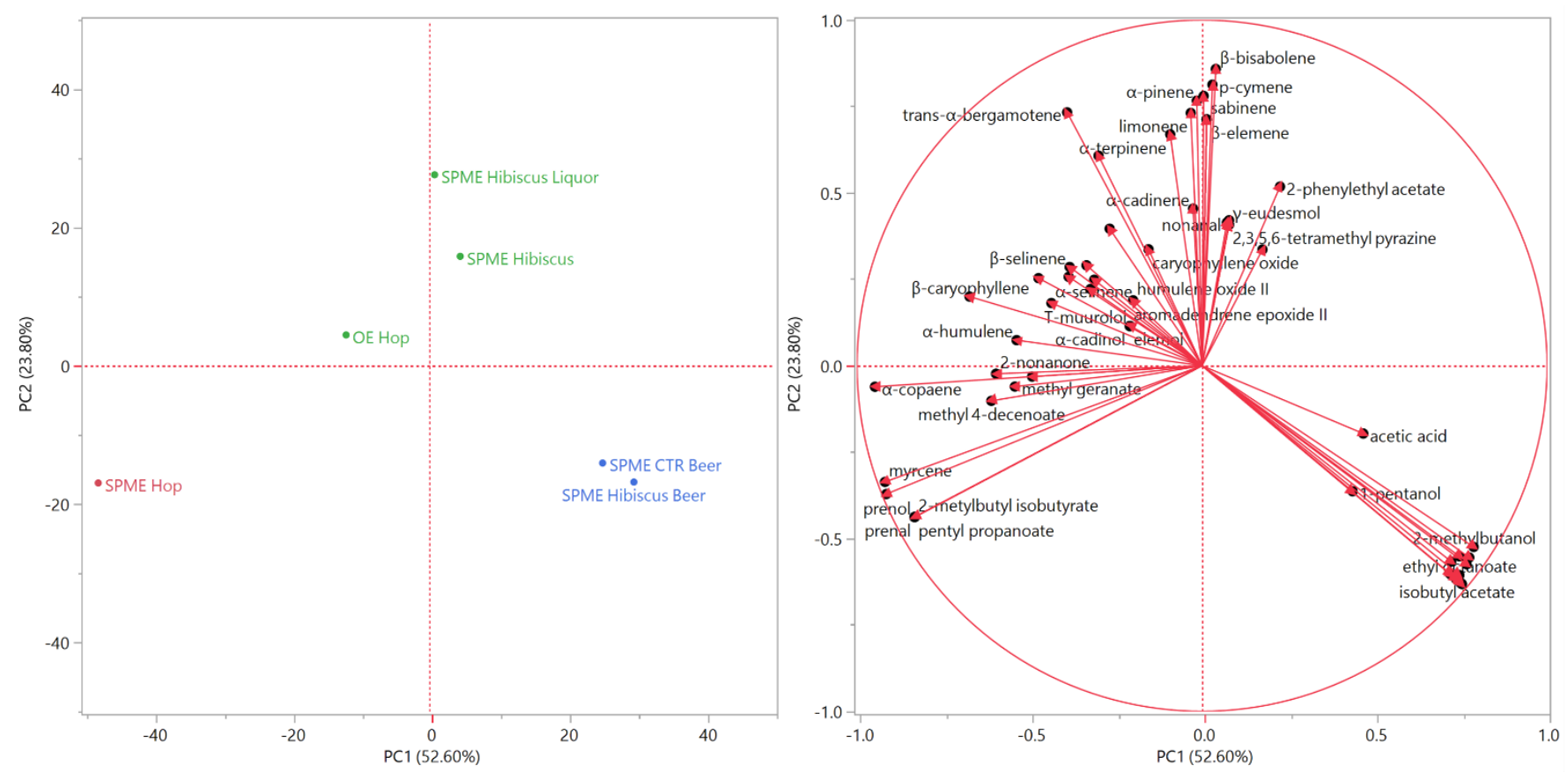

Figure 4. Score (left) and loading (right) plots of the principal component analysis (PCA) performed on the complete composition of the Cascade hop EO and the headspaces of the plant materials and the beverages.

The distribution of the samples in the score plot was comparable to the clustering of the PCA analysis. SPME Hop was plotted by itself in the leftmost area of the bottom left quadrant (PC1 and PC2 <0): greater distance to all other analyzed samples evidenced low compositional similarities. Both beer samples were positioned close to each other in the lower right quadrant $(\mathrm{PC} 1>0$ and $\mathrm{PC} 2<0)$, probably due to their relevant content in non-terpene esters, whose vectors were directed towards the rightmost area of the bottom right quadrant. Finally, the samples of the green cluster of the HCA analysis were plotted in the upper quadrants (PC2 $>0)$, near the separation line between the left and the right ones. The positioning of the sample hop EO in the upper left quadrant was probably due to the $\alpha$-humulene and $\beta$-caryophyllene vectors, whilst the hibiscus liqueur was plotted in the middle area of the upper quadrant because of the high relative content in limonene, whose vector pointed towards the same area of the score plot.

\subsection{Sensorial Analysis}

The scores and the radar graph of the QDA sensorial analysis for both the control and the treated samples are reported in Table 6 and in Figure 5, respectively.

In the descriptive analysis, the control beer showed no turbidity and medium foam persistency. In the olfactory and gustative phase intensity, malty and hoppy notes were highlighted, confirming the noticeable relative content of myrcene and $\alpha$-humulene in the CTR Beer HS. The treated beer (hibiscus beer) showed high foam persistency and low turbidity and was mainly characterized by floral and fruity notes in the olfactory phase, which can be also found in the gustatory one, with sour, floral, fruity and salty as the main attributes; in particular, the panel evidenced a flavor similar to red fruits and flowers such as blueberry, rabes and rosehip. The floral and fruity scents could be attributable to the predominance of non-terpene esters and alcohols in the volatilome of the beer. 
Table 6. Average scores of the QDA analysis attributes for control and hibiscus beers.

\begin{tabular}{|c|c|c|}
\hline & Control Beer & Hibiscus Beer \\
\hline \multicolumn{3}{|l|}{ Odor attribute } \\
\hline Overall intensity & 3 & 4 \\
\hline Malty & 6 & 2 \\
\hline Hoppy & 4 & 1 \\
\hline Floral & 3 & 6 \\
\hline Fruity & 0 & 5 \\
\hline Spicy & 0 & 2 \\
\hline Honey & 0 & 0 \\
\hline Roasted & 0 & 0 \\
\hline \multicolumn{3}{|l|}{ Visual attribute } \\
\hline Foam persistency & 4 & 7 \\
\hline Turbidity & 2 & 3 \\
\hline \multicolumn{3}{|l|}{ Gustatory attribute } \\
\hline Overall intensity & 3 & 5 \\
\hline Sweet & 0 & 0 \\
\hline Bitter & 3 & 2 \\
\hline Salty & 0 & 2 \\
\hline Sour & 0 & 4 \\
\hline Alcohol & 2 & 2 \\
\hline Malty & 6 & 1 \\
\hline Hoppy & 4 & 2 \\
\hline Floral & 2 & 6 \\
\hline Fruity & 2 & 5 \\
\hline Spicy & 0 & 2 \\
\hline Honey & 0 & 0 \\
\hline Roasted & 0 & 0 \\
\hline \multicolumn{3}{|l|}{ Texture attribute } \\
\hline Fullness & 2 & 2 \\
\hline Texture attribute & 4 & 4 \\
\hline Astringent & 2 & 4 \\
\hline
\end{tabular}



Figure 5. Radar graph of QDA analysis of control and treated beers. 


\subsection{Biochemical Analyses}

Total chlorophylls and total carotenoids (Table 7) were determined in the dried plant materials used for the production of the studied alcoholic beverages. The total chlorophylls content was higher in the H. lupulus cones, as it reached $671.77 \mu \mathrm{g} / \mathrm{g} \mathrm{DW}$, than in the $H$. rosa-sinensis flowers, which presented $8.28 \mu \mathrm{g} / \mathrm{g}$ DW. On the contrary, carotenoids were more abundant in the latter $(229.29 \mu \mathrm{g} / \mathrm{g}$ DW) than in the former $(161.17 \mu \mathrm{g} / \mathrm{g} \mathrm{DW})$.

Table 7. Determination of pigments, secondary metabolites, and antioxidant activity of $H$. rosa-sinensis flowers, $H$. lupulus cones, control beer, hibiscus beer and hibiscus liqueur. Abbreviations: DW—dry weight; GAE-gallic acid equivalents; CE-catechin equivalents.

\begin{tabular}{|c|c|c|c|c|c|}
\hline & $\begin{array}{c}\text { Hibiscus } \\
\text { rosa-sinensis L. } \\
\text { Flowers }\end{array}$ & $\begin{array}{c}\text { Humulus lupulus } \\
\text { cv. Cascade L. } \\
\text { Cones }\end{array}$ & Control Beer & Hibiscus Beer & $\begin{array}{l}\text { Hibiscus } \\
\text { Liqueur }\end{array}$ \\
\hline $\begin{array}{c}\text { Total chlorophylls } \\
(\mu \mathrm{g} / \mathrm{g} D W)\end{array}$ & $8.28 \pm 1.69$ & $671.77 \pm 65.64$ & & & \\
\hline $\begin{array}{l}\text { Total carotenoids } \\
(\mu \mathrm{g} / \mathrm{g} D W)\end{array}$ & $229.29 \pm 24.26$ & $161.17 \pm 7.66$ & & & \\
\hline $\begin{array}{l}\text { Total anthocyanins } \\
(\mathrm{mg} / \mathrm{g} \text { DW })\end{array}$ & $16.26 \pm 0.98$ & nd & & & \\
\hline $\begin{array}{l}\text { Total anthocyanins } \\
\qquad(\mu \mathrm{g} / \mathrm{mL})\end{array}$ & & & $\mathrm{nd}^{\mathrm{b}}$ & $2.76 \pm 0.26^{a}$ & $134.21 \pm 5.24$ \\
\hline $\begin{array}{l}\text { Total flavonoids } \\
(\mathrm{mg} \text { CE/g DW) }\end{array}$ & $73.91 \pm 6.9$ & $27.29 \pm 1.89$ & & & \\
\hline $\begin{array}{l}\text { Total flavonoids } \\
(\mu \mathrm{g} \mathrm{CE} / \mathrm{mL})\end{array}$ & & & $201.37 \pm 5.83^{b}$ & $360.66 \pm 4.72^{\mathrm{a}}$ & $741.26 \pm 5.83$ \\
\hline $\begin{array}{l}\text { Total polyphenols } \\
\text { (mg GAE/g DW) }\end{array}$ & $114.57 \pm 4.89$ & $99.45 \pm 5.68$ & & & \\
\hline $\begin{array}{l}\text { Total polyphenols } \\
(\mu \mathrm{g} \text { GAE } / \mathrm{mL})\end{array}$ & & & $350.31 \pm 9.42^{b}$ & $436.26 \pm 15.57^{a}$ & $847.66 \pm 36.95$ \\
\hline $\begin{array}{c}\text { DPPH-assay } \\
\text { scavenging effect \% }\end{array}$ & $75.7 \pm 0.29$ & $62.62 \pm 1.95$ & $35.79 \pm 0.97^{b}$ & $74.71 \pm 6.94^{\mathrm{a}}$ & $73.45 \pm 6.65$ \\
\hline
\end{tabular}

The superscript lowercase letters ${ }^{\mathrm{a}}$ and ${ }^{\mathrm{b}}$ indicate statistically significant differences between the control and the treated beers. The statistically significance was determined by Tukey's post hoc test, with $p \leq 0.05$; nd: not detected.

The red pigmentation of the hibiscus flowers was attributable to the anthocyanins, phenolic compounds responsible for the colors in fruits and vegetables widely used in the food industry as natural colorant [40]. Their content, reported in Table 7, was determined in both the analyzed plant materials and the studied alcoholic beverages. Unsurprisingly, the hibiscus flowers presented a noticeable amount of these chemical compounds $(16.26 \mathrm{mg} / \mathrm{g}$ DW), while they were not detected in the hop cones. Regarding the beverages, the highest anthocyanin content was in the hibiscus liqueur, which presented $134.21 \mu \mathrm{g} / \mathrm{mL}$. The hibiscus beer, instead, was characterized by a strongly lower content than the liqueur, as it showed $2.76 \mu \mathrm{g} / \mathrm{g}$. However, the amounts of this class of secondary metabolites were significantly higher in the hibiscus beer than in the control one, in which they were not present. The presence of anthocyanins in the beer was probably due to the hibiscus flowers, as they usually are not reported as main phenolic compounds of beer [41].

On the contrary, flavonoids are key components of this alcoholic beverage since they contribute to its astringency and bitterness [41,42]. The total flavonoid contents (TFCs) were also assessed in all the samples, with their highest presence in the hibiscus flowers (73.91 $\mathrm{mg} \mathrm{CE} / \mathrm{g} \mathrm{DW}$ ) and hop cones (27.29 $\mathrm{mg} \mathrm{CE} / \mathrm{g} \mathrm{DW})$, and among the beverages, the hibiscus liqueur $(741.26 \mu \mathrm{g} / \mathrm{mL})$. Concerning the beer samples, the TFCs were significantly more abundant in the treated beer $(360.66 \mu \mathrm{g} C E / \mathrm{mL})$ than in the control one (201.37 $\mu \mathrm{g} \mathrm{CE} / \mathrm{mL})$.

Finally, the total polyphenol content (TPC) was investigated for all the samples. Both the plant materials presented suitable amounts of polyphenols, even if they were more abundant in the hibiscus flowers (114.57 mg GAE/g) than in the hop cones (99.45 mg GAE/g). The 
TPCs, as the anthocyanins, were highest in the hibiscus liqueur (847.66 $\mu \mathrm{g} \mathrm{GAE} / \mathrm{mL})$, while the hibiscus beer presented a significantly higher amount than the control beer (436.26 $>350.31 \mu \mathrm{g}$ GAE/mL). Polyphenols are chemical compounds comprising several classes of compounds, including flavonoids and anthocyanins. In beer, they are mainly derived from the malt or the cereal used for the brewing process [41]. However, the type and the quality of the used raw materials can also significantly affect their content [42]. In the present work the addition of the hibiscus flowers to the beer resulted in an increase in these chemicals, which are of the utmost importance in the brewing process, as they can affect several characters of the beer such as the astringency, body and fullness, as well as the taste and aroma [41]. Moreover, polyphenols have a key role in the prevention of oxidation, since they are able to chelate free metals and neutralize free radicals with different mechanism of action - this could lead to an improvement of the product stability and to an increase in the shelf-life [43]. The radical scavenger activity of the samples was also assessed with a DPPH assay and expressed as a DPPH scavenging effect (\%). The $H$. rosa sinensis plant samples showed higher activity than the hop cones, following the tendency of the antioxidant metabolites. The beverages with hibiscus, either the beer or the liqueur, exhibited strong scavenging effects of $74.71 \%$ and $73.45 \%$, respectively, while the control beer showed half the activity.

\section{Conclusions}

The aroma of the beer samples, both the control and the treated one, was characterized by a predominance of non-terpene derivatives, which, however, were significantly more abundant in the hibiscus beer than in the control one. Within this chemical class, esters and alcohols, the molecules responsible for fruity and floral notes, were the most represented constituents.

The sensory analysis evidenced that the use of dried hibiscus flowers during the end of the boiling and whirlpool phases conferred a unique and peculiar taste and aroma to the finished beer. The flavor was characterized by red flowers and red berries, reminiscent of rosehip and blueberry. The taste olfactory part is even more interesting, as the acidastringent component emerged with a slight savory note. The complexity of the hibiscus flower makes the beer pleasant to drink, reminiscent of a good prosecco or a low-alcohol sparkling rosé wine.

Finally, the biochemical analysis evidenced a higher content of total polyphenols, total flavonoids and total anthocyanins in the hibiscus-flavored beer compared to the control one. The antioxidant activity reflects the behavior of antioxidant molecules.

The use of aromatic plants in the production of craft beer, particularly beer with a low alcohol content, could open the doors not only to new recipes but also to new nutraceutical foods with improved nutraceutical properties.

Author Contributions: Conceptualization, G.F., L.P. (Luisa Pistelli), R.A. and M.I.; methodology, Y.P. and M.L.; software, Y.P., M.L. and R.A.; formal analysis, Y.P., L.P. (Laura Pistelli) and M.L.; investigation, Y.P., L.P. (Laura Pistelli), M.L., R.A., M.I. and A.M.; resources, G.F., L.P. (Luisa Pistelli), L.P. (Laura Pistelli) and M.I.; data curation, G.F., L.P. (Luisa Pistelli), L.P. (Laura Pistelli), Y.P., M.I. and A.M.; writing—original draft preparation, Y.P., L.P. (Laura Pistelli), M.I. and A.M.; writing-review and editing, G.F., L.P. (Luisa Pistelli), R.A., L.P. (Laura Pistelli), M.I. and A.M; supervision, G.F., L.P. (Luisa Pistelli), L.P. (Laura Pistelli) and M.I.; project administration, G.F., L.P. (Luisa Pistelli) and M.I.; funding acquisition, G.F., L.P. (Luisa Pistelli) and L.P. (Laura Pistelli). All authors have read and agreed to the published version of the manuscript.

Funding: This research received no external funding.

Institutional Review Board Statement: Not applicable.

Informed Consent Statement: Not applicable.

Data Availability Statement: Data are contained within the article.

Conflicts of Interest: The authors declare no conflict of interest. 


\section{References}

1. Willaert, R. Beverages: The Beer Brewing Process: Wort Production and Beer Fermentation. In Handbook of Food Products Manufacturing; Hui, Y.H., Chandan, R.C., Clark, S., Cross, N.A., Dobbs, J.C., Hurst, W.J., Nollet, L.M.L., Shimoni, E., Smith, E.B., Surapat, S., et al., Eds.; John Wiley \& Sons: Hoboken, NJ, USA, 2006; Section V; Volume 1, ISBN 9780470049648.

2. Da Costa Jardim, C.; de Souza, D.; Cristina Kasper Machado, I.; Massochin Nunes Pinto, L.; de Souza Ramos, R.; Garavaglia, J. Sensory Profile, Consumer Preference and Chemical Composition of Craft Beers from Brazil. Beverages 2018, 4, 106. [CrossRef]

3. Estela-Escalante, W.D.; Rosales-Mendoza, S.; Moscosa-Santillán, M.; González-Ramírez, J.E. Evaluation of the fermentative potential of Candida zemplinina yeasts for craft beer fermentation. J. Inst. Brew. 2016, 122, 530-535. [CrossRef]

4. Aquilani, B.; Laureti, T.; Poponi, S.; Secondi, L. Beer choice and consumption determinants when craft beers are tasted: An exploratory study of consumer preferences. Food Qual. Prefer. 2015, 41, 214-224. [CrossRef]

5. Guido, L.F. Brewing and Craft Beer. Beverages 2019, 5, 51. [CrossRef]

6. Baigts-Allende, D.K.; Pérez-Alva, A.; Ramírez-Rodrigues, M.A.; Palacios, A.; Ramírez-Rodrigues, M.M. A comparative study of polyphenolic and amino acid profiles of commercial fruit beers. J. Food Compos. Anal. 2021, 100, 103921. [CrossRef]

7. Ascrizzi, R.; Iannone, M.; Cinque, G.; Marianelli, A.; Pistelli, L.; Flamini, G. "Hemping" the drinks: Aromatizing alcoholic beverages with a blend of Cannabis sativa L. flowers. Food Chem. 2020, 325, 126909. [CrossRef]

8. Vera, L.; Aceña, L.; Guasch, J.; Boqué, R.; Mestres, M.; Busto, O. Characterization and classification of the aroma of beer samples by means of an MS e-nose and chemometric tools. Anal. Bioanal. Chem. 2011, 399, 2073-2081. [CrossRef] [PubMed]

9. Hughes, P. Beer flavor. In Beer; Bamforth, C., Russell, I., Stewart, G., Eds.; Elsevier: Amsterdam, The Netherlands, 2009 ; pp. 61-83. ISBN 9780126692013.

10. Pistelli, L.; Ferri, B.; Cioni, P.L.; Koziara, M.; Agacka, M.; Skomra, U. Aroma profile and bitter acid characterization of hop cones (Humulus lupulus L.) of five healthy and infected Polish cultivars. Ind. Crops Prod. 2018, 124, 653-662. [CrossRef]

11. Langstaff, B.S.A.; Lewis, M.J. The mouthfeel of beer-A Review. J. Inst. Brew. 1993, 99, 31-37. [CrossRef]

12. Gonzalez Viejo, C.; Fuentes, S.; Torrico, D.D.; Godbole, A.; Dunshea, F.R. Chemical characterization of aromas in beer and their effect on consumers liking. Food Chem. 2019, 293, 479-485. [CrossRef] [PubMed]

13. Carvalho, F.R.; Moors, P.; Wagemans, J.; Spence, C. The influence of color on the consumer's experience of beer. Front. Psychol. 2017, 8, 1-9. [CrossRef]

14. Takahashi, J.A.; Rezende, F.A.G.G.; Moura, M.A.F.; Dominguete, L.C.B.; Sande, D. Edible flowers: Bioactive profile and its potential to be used in food development. Food Res. Int. 2020, 129, 108868. [CrossRef]

15. Sivaraman, C.M.; Saju, F. Medicinal value of Hibiscus rosa sinensis: A review. Int. J. Pharmacogn. Chem. 2021, 2, 1-11. [CrossRef]

16. Missoum, A. An update review on Hibiscus rosa sinensis phytochemistry and medicinal uses. J. Ayurvedic Herb. Med. 2018, 4, 135-146. [CrossRef]

17. Jadhav, V.; Thorat1, R.M.; Sathe, N.; Kadam, V. Hibiscus rosa sinenis Linn-“Rudrapuspa”: A Review. J. Pharm. Res. 2009, 2, $1168-1173$.

18. Rengarajan, S.; Melanathuru, V.; Govindasamy, C.; Chinnadurai, V.; Elsadek, M.F. Antioxidant activity of flavonoid compounds isolated from the petals of Hibiscus rosa sinensis. J. King Saud Univ.Sci. 2020, 32, 2236-2242. [CrossRef]

19. Aron, P.M.; Shellhammer, T.H. A Discussion of Polyphenols in Beer Physical and Flavour Stability. J. Inst. Brew. 2010, 116, 369-380. [CrossRef]

20. Anokwuru, P.C.; Esiaba, I.; Ajbaye, O.; Adesuyi, A.O. Polyphenolic Content and Antioxidant Activity of Hibiscus sabdariffa Calyx. Res. J. Med. Plant 2011, 5, 557-566. [CrossRef]

21. Oladokun, O.; Tarrega, A.; James, S.; Smart, K.; Hort, J.; Cook, D. The impact of hop bitter acid and polyphenol profiles on the perceived bitterness of beer. Food Chem. 2016, 205, 212-220. [CrossRef] [PubMed]

22. Medoro, C.; Cianciabella, M.; Camilli, F.; Magli, M.; Gatti, E.; Predieri, S. Sensory Profile of Italian Craft Beers, Beer Taster Expert versus Sensory Methods: A Comparative Study. Food Nutr. Sci. 2016, 07, 454-465. [CrossRef]

23. Adams, R.P. Identification of Essential Oil Components by Gas Chromatography/Mass Spectroscopy; Carol Stream, Ed.; Allured Publishing Corporation: Carol Stream, IL, USA, 2007; ISBN 1932633219.

24. Davies, N.W. Gas chromatographic retention indices of monoterpenes and sesquiterpenes on Methyl Silicon and Carbowax 20M phases. J. Chromatogr. A 1990, 503, 1-24. [CrossRef]

25. Jennings, W.; Shibamoto, T. Qualitative Analysis of Flavor and Fragrance Volatiles by Glass Capillary Gas Chromatography; Academic Press: New York, NY, USA, 1982; Volume 26.

26. Masada, Y. Analysis of Essential Oils by Gas Chromatography and Mass Spectrometry; John Wiley \& Sons, Inc.: New York, NY, USA, 1976; ISBN 047015019X.

27. Stenhagen, E.; Abrahamsson, S.; McLafferty, F.W. Registry of Mass Spectral Data; Wiley \& Sons: New York, NY, USA, 1974.

28. Swigar, A.A.; Silverstein, R.M. Monoterpenes; Aldrich Chemical Company: Milwaukee, WI, USA, 1981.

29. Lichtenthaler, H.K. Chlorophylls and carotenoids: Pigments of photosynthetic biomembranes. In Methods in Enzymology; Elsevier: Amsterdam, The Netherlands, 1987; Volume 148, pp. 350-382.

30. Lee, J.; Durst, R.W.; Wrolstad, R.E.; Eisele, T.; Giusti, M.M.; Hach, J.; Hofsommer, H.; Koswig, S.; Krueger, D.A.; Kupina, S.; et al. Determination of Total Monomeric Anthocyanin Pigment Content of Fruit Juices, Beverages, Natural Colorants, and Wines by the pH Differential Method: Collaborative Study. J. AOAC Int. 2005, 88, 1269-1278. [CrossRef] 
31. Giusti, M.M.; Wrolstad, R.E. Characterization and Measurement of Anthocyanins by UV-Visible Spectroscopy. Curr. Protoc. Food Anal. Chem. 2001, F1.2.1-F1.2.13. [CrossRef]

32. Singleton, V.L.; Rossi, J.A.J. Colorimetry to total phenolics with phosphomolybdic acid reagents. Am. J. Enol. Vinic. 1965, 16, 144-158.

33. Kim, D.-O.; Jeong, S.W.; Lee, C.Y. Antioxidant capacity of phenolic phytochemicals from various cultivars of plums. Food Chem. 2003, 81, 321-326. [CrossRef]

34. Brand-Williams, W.; Cuvelier, M.E.; Berset, C. Use of a free radical method to evaluate antioxidant activity. LWT-Food Sci. Technol. 1995, 28, 25-30. [CrossRef]

35. Hammer, Ø.; Harper, D.A.T.; Ryan, P.D. PAST: Paleontological statistics soft-ware package for education and data analysis. Palaeontol. Electron. 2001, 4, 9.

36. Nance, M.R.; Setzer, W.N. Volatile components of aroma hops (Humulus lupulus L.) commonly used in beer brewing. J. Brew. Distill. 2011, 2, 16-22.

37. Forteschi, M.; Porcu, M.C.; Fanari, M.; Zinellu, M.; Secchi, N.; Buiatti, S.; Passaghe, P.; Bertoli, S.; Pretti, L. Quality assessment of "Cascade" Hop (Humulus lupulus L.) grown in Sardinia. Eur. Food Res. Technol. 2019, 245, 863-871. [CrossRef]

38. Alves, V.; Gonçalves, J.; Figueira, J.A.; Ornelas, L.P.; Branco, R.N.; Câmara, J.S.; Pereira, J.A.M. Beer volatile fingerprinting at different brewing steps. Food Chem. 2020, 326, 126856. [CrossRef] [PubMed]

39. Holt, S.; Miks, M.H.; de Carvalho, B.T.; Foulquié-Moreno, M.R.; Thevelein, J.M. The molecular biology of fruity and floral aromas in beer and other alcoholic beverages. FEMS Microbiol. Rev. 2019, 43, 193-222. [CrossRef] [PubMed]

40. Khoo, H.E.; Azlan, A.; Tang, S.T.; Lim, S.M. Anthocyanidins and anthocyanins: Colored pigments as food, pharmaceutical ingredients, and the potential health benefits. Food Nutr. Res. 2017, 61, 1361779. [CrossRef] [PubMed]

41. Habschied, K.; Lončarić, A.; Mastanjević, K. Screening of Polyphenols and Antioxidative Activity in Industrial Beers. Foods 2020, 9, 238. [CrossRef]

42. Habschied, K.; Košir, I.J.; Krstanović, V.; Kumrić, G.; Mastanjević, K. Beer Polyphenols—Bitterness, Astringency, and Off-Flavors. Beverages 2021, 7, 38. [CrossRef]

43. Leopoldini, M.; Russo, N.; Toscano, M. The molecular basis of working mechanism of natural polyphenolic antioxidants. Food Chem. 2011, 125, 288-306. [CrossRef] 